\title{
THE ADOLESCENCE OF NUTRITION*
}

\author{
BY \\ L. EMMETT HOLT, JR. \\ From New York University College of Medicine
}

The title of my lecture implies a degree of clairvoyance as to the future of nutrition which I am sure I do not possess. Nevertheless it is fun at times to indulge in speculation. In a field in which one is working it is also necessary for one's peace of mind to take an occasional long look ahead to make sure that one is on what seems to be the right path.

Nutrition has been the handmaiden of paediatrics for a long time. It has served us well, has helped us enormously in reducing infant mortality and morbidity, and we in turn with our problem of infant feeding have been the chief clinical group to apply nutritional knowledge. We have learned to feed children successfully and we think we know why we are successful. We think we know what the essential nutrients are almost, if not completely, and we have an extensive knowledge about quantitative requirements.

Has nutrition indeed virtually completed its task? Should we look now to other preclinical disciplines to help us in the future? Should our young would-be investigators be steered toward other tools? You may suspect from my title that this is not my thought for I believe that the contributions which nutrition can make to us in the future are quite as bright as those of the past, if not brighter. But before I develop my thesis that nutrition is only nearing the end of the first phase of its development, its infancy and childhood, and before I undertake to point out the beginning signs of puberty and sketch what may be its adult pattern, I want to say a few words about the childhood of nutrition and our own stake in it, the nutritional needs of the normal child.

The foundations of knowledge of the nutritional requirements of the child were laid in the last century, an era which lasted up to World War I. Energy requirements were reasonably well established and much was learned about the requirements for nitrogen and the major minerals. This knowledge came from many workers in different countries, but notably from the German school, of which Czerny

* Windermere Lecture delivered before the British Paediatric Association, April 26, 1956. and Keller were the outstanding examples. What was termed 'the newer knowledge of nutrition' was born about the time of World War I. The accessory food factors then came into view as did the essential amino-acids, and to these have been added many trace minerals. These epoch-making discoveries gave nutrition a prominent place among the medical disciplines. In paediatrics we have witnessed a gradual revolution in our thinking about feeding problems; nutrition has largely replaced digestion as a guide in feeding. Digestive disorders there are and doubtless will be for some time to come. They were formerly attributed to the food. We used to look at the stools to guide us in feeding, either at the stools themselves or at various hieroglyphics on the chart designed to describe them. Their return to normal was the measure of success, but today little attention is paid to them. We look at them only to ascertain roughly the extent of the nutritional handicap we are faced with, and we bend our efforts to overcoming that handicap and meeting nutritional requirements. With rare exceptions we no longer attribute digestive disturbances to the food but to circumstances quite apart from and uninfluenced by the food, notably infections, enteric and parenteral. The pioneers of this revolution said their say in the early 1920 s, Marriott and Park in our country and Schick and Wagner in Vienna, but it took a long time for their points of view to find general acceptance. They appreciated clearly the fallacy of using the stools as a guide and the desirability of feeding the child what he needed, regardless of intestinal tolerance.

Perhaps it was impatience on my part at the slow acceptance of what seemed sound, perhaps the realization that this was in part due to the paucity of supporting data. At any rate our group in New York undertook some 10 years ago to obtain data which would answer what seemed to be the two fundamental questions concerned in feeding the patient with some form of intestinal intolerance: (1) Is food absorption benefited by feeding a poorly tolerated foodstuff? (2) Is recovery delayed by such feeding? 
TABLE 1

EFFECT OF QUANTITY OF ORAL FEEDING ON FOOD ABSORPTION IN INFANTILE DIARRHOEA (From Chung, 1949)

\begin{tabular}{|c|c|c|c|c|c|c|c|c|c|}
\hline Cas & se 19 & $\begin{array}{c}\text { Water } \\
\text { (ml./day) }\end{array}$ & $\underset{\text { (g. day) }}{\text { Ash }}$ & $\underset{(\mathrm{mEq} / \text { day })}{\mathbf{N a}}$ & $\underset{(m E q / \text { day })}{K}$ & $\underset{\text { (mEq/day) }}{\mathrm{Ca}}$ & $\underset{\text { (mEq/day) }}{\mathrm{Cl}}$ & $\begin{array}{c}\text { Fat } \\
\text { (g. day) }\end{array}$ & $\underset{\text { (g. } / \text { day) }}{\mathbf{N}}$ \\
\hline \multirow[t]{2}{*}{$\begin{array}{l}\text { Low intake } \\
\text { ( } 24 \text { cal. } \mathrm{kg} .)\end{array}$} & \multirow{2}{*}{$\begin{array}{l}\text { Orai intake } \\
\text { Faeces } \\
\text { Absorbed } \\
\text { \% Intake } \\
\text { absorbed }\end{array}$} & $\begin{array}{l}960 \\
156 \\
804\end{array}$ & $\begin{array}{r}1 \cdot 58 \\
2.45 \\
-0.87\end{array}$ & $\begin{array}{r}5 \cdot 6 \\
7 \cdot 2 \\
-1 \cdot 6\end{array}$ & $\begin{array}{r}8 \cdot 3 \\
9 \cdot 4 \\
-1 \cdot 1\end{array}$ & $\begin{array}{r}12 \cdot 8 \\
20 \cdot 8 \\
-8 \cdot 0\end{array}$ & $\begin{array}{r}6 \cdot 8 \\
12 \cdot 0 \\
-5 \cdot 2\end{array}$ & $\begin{array}{r}7 \cdot 35 \\
3 \cdot 42 \\
-3 \cdot 93\end{array}$ & $\begin{array}{r}1 \cdot 15 \\
0.46 \\
-0.69\end{array}$ \\
\hline & & 84 & - & - & - & - & - & 53 & 60 \\
\hline \multirow[t]{2}{*}{$\begin{array}{l}\text { Medium } \\
\text { intake } \\
(49 \mathrm{cal} . / \mathrm{kg})\end{array}$} & \multirow{2}{*}{$\begin{array}{l}\text { Oral intake } \\
\text { Faeces } \\
\text { Absorbed } \\
\text { \% Intake } \\
\text { absorbed }\end{array}$} & $\begin{array}{r}1,200 \\
168 \\
1,032\end{array}$ & $\begin{array}{r}3 \cdot 16 \\
2 \cdot 31 \\
-0 \cdot 85\end{array}$ & $\begin{array}{l}11 \cdot 2 \\
11 \cdot 7 \\
0 \cdot 5\end{array}$ & $\begin{array}{r}16 \cdot 6 \\
9 \cdot 5 \\
-7 \cdot 1\end{array}$ & $\begin{aligned} & 25 \cdot 6 \\
& 19 \cdot 5 \\
- & 6 \cdot 1\end{aligned}$ & $\begin{array}{r}13 \cdot 6 \\
11 \cdot 9 \\
-1 \cdot 7\end{array}$ & $\begin{array}{c}14 \cdot 70 \\
5 \cdot 60 \\
-9 \cdot 10\end{array}$ & $\begin{array}{r}2 \cdot 30 \\
0 \cdot 42 \\
-1 \cdot 88\end{array}$ \\
\hline & & 86 & 27 & - & 43 & 24 & 13 & 62 & 82 \\
\hline \multirow[t]{2}{*}{$\begin{array}{l}\text { High intake } \\
\text { (100 cal. } / \mathrm{kg} \text { ) }\end{array}$} & \multirow{2}{*}{$\begin{array}{l}\text { Oral intake } \\
\text { Faeces } \\
\text { Absorbed } \\
\text { \% Intake } \\
\text { absorbed }\end{array}$} & $\begin{array}{r}1,410 \\
270 \\
1,140\end{array}$ & $\begin{array}{r}6 \cdot 32 \\
4 \cdot 50 \\
-1 \cdot 82\end{array}$ & $\begin{array}{r}22 \cdot 4 \\
18 \cdot 1 \\
-\quad 4 \cdot 3\end{array}$ & $\begin{array}{r}33 \cdot 2 \\
12 \cdot 3 \\
-20 \cdot 9\end{array}$ & $\begin{array}{r}51 \cdot 2 \\
42 \cdot 7 \\
-\quad 8 \cdot 5\end{array}$ & $\begin{array}{r}27 \cdot 2 \\
21 \cdot 6 \\
-\quad 5 \cdot 6\end{array}$ & $\begin{array}{r}29 \cdot 40 \\
12 \cdot 10 \\
-17 \cdot 30\end{array}$ & $\begin{array}{r}4 \cdot 60 \\
0 \cdot 50 \\
-4 \cdot 10\end{array}$ \\
\hline & & 81 & 29 & 19 & 63 & 17 & 27 & 59 & 88 \\
\hline
\end{tabular}

Our studies have involved five conditions associated with intestinal intolerance: acute diarrhoea and several conditions associated with steatorrhoea, namely, coeliac disease, cystic fibrosis of the pancreas, biliary obstruction and prematurity. I shall present only a few illustrative examples, since details of these studies are published elsewhere (Chung, 1948; Chung and Viščorová, 1948; Chung and Holt, 1950; Chung, Morales, Snyderman, Lewis and Holt, 1951; Morales, Chung, Lewis, Messina and Holt, 1950; Krahulik, Shoob, Morales, Snyderman and Holt, 1952).

Table 1 illustrates balance data on nitrogen, fat and several minerals in an infant with diarrhoea studied at three different levels of food intake. Net absorption of each foodstuff is increased by increasing the intake despite additional stool losses. This

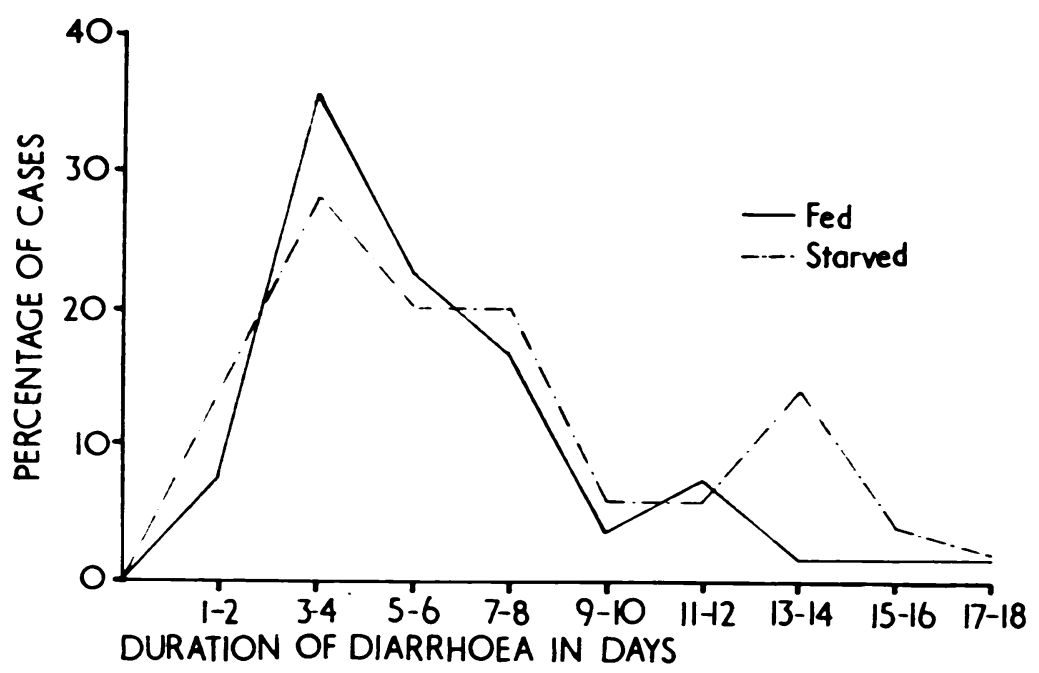

finding, which we observed consistently, points to the value of a generous food intake. Fig. 1 illustrates the duration of diarrhoea in two groups of patients, one treated with initial therapeutic starvation, the other with full feedings from the start. It is apparent that initial starvation fails to accelerate recovery. The policy of feeding cases of diarrhoea which is supported by these studies is not recommended as a substitute for parenteral therapy. Obviously the oral route is inadequate to maintain nutrition in severe disorders, but it is recommended to supplement whatever parenteral therapy may be necessary and in the absence of vomiting much useful food can be so introduced.

In the steatorrhoeas we have tested the effect of generous fat supplements on the absorption of fat and other foodstuffs. We find consistently that fat tolerance, judged by the percentage of fat intake absorbed, is unaffected by the fat load within the limits studied; increasing the intake increases stool loss but also the amount of fat absorbed which is what we are interested in. Table 2 illustrates this in a patient with coeliac disease, whose improved nutrition is illustrated in the next figure. Table 3 gives similar data on a case of cystic fibrosis;

Fig. 1.-Influence of early feeding on duration of infantile diarrhoea (from Chung and Viscorova, 1948). 
TABLE 2

EFFECT OF ADDING EXCESS FAT TO THE DIET OF A COELIAC PATIENT, AGED $7 \frac{1}{2}$ YEARS.

(From Chung et al., 1951)

\begin{tabular}{|c|c|c|c|c|c|c|c|c|c|c|c|}
\hline & & $\begin{array}{l}\text { Water } \\
\text { (ml. day) }\end{array}$ & $\underset{\text { (g./day) }}{\text { Ash }}$ & $\underset{\text { (mEq/day) }}{\mathrm{Na}}$ & $\underset{\mathrm{mEq} / \text { day) }}{\mathbf{K}}$ & $\underset{(m E q / d a y)}{C a}$ & $\underset{(m E q / \text { day })}{P}$ & $\underset{(m E q / d a y)}{C l}$ & $\underset{\text { (g./day) }}{\text { Fat }}$ & $\begin{array}{l}\mathrm{N} \\
\text { (g. day) }\end{array}$ & $\begin{array}{l}\text { Weight } \\
\text { (kg.) }\end{array}$ \\
\hline \multirow[t]{2}{*}{$\begin{array}{c}\text { Control } \\
\text { diet }\end{array}$} & \multirow{2}{*}{$\begin{array}{l}\text { Intake } \\
\text { Urine } \\
\text { Faeces } \\
\text { Absorbed } \\
\text { \% Intake } \\
\text { absorbed }\end{array}$} & $\begin{array}{r}1,920 \\
525 \\
186 \\
1,734\end{array}$ & $\begin{array}{r}14 \cdot 84 \\
5 \cdot 40 \\
5 \cdot 35 \\
9 \cdot 49\end{array}$ & $\begin{array}{r}50 \cdot 0 \\
33 \cdot 3 \\
4 \cdot 7 \\
45 \cdot 3\end{array}$ & $\begin{array}{r}79 \cdot 0 \\
48 \cdot 4 \\
7 \cdot 0 \\
72 \cdot 0\end{array}$ & $\begin{array}{r}168 \cdot 0 \\
0 \cdot 6 \\
81 \cdot 5 \\
86 \cdot 5\end{array}$ & $\begin{array}{l}52 \cdot 6 \\
12 \cdot 5 \\
19 \cdot 1 \\
33 \cdot 5\end{array}$ & $\begin{array}{r}46 \cdot 0 \\
25 \cdot 8 \\
0 \cdot 9 \\
45 \cdot 1\end{array}$ & $\begin{array}{l}76 \cdot 80 \\
41 \cdot 50 \\
35 \cdot 25\end{array}$ & $\begin{array}{l}8 \cdot 06 \\
2 \cdot 98 \\
1 \cdot 53 \\
6 \cdot 53\end{array}$ & $20 \cdot 6$ \\
\hline & & 90 & 64 & 91 & 91 & 52 & 64 & 98 & 46 & 81 & \\
\hline $\begin{array}{l}\text { Control } \\
\text { diet } \\
-85 \cdot 4 \mathrm{~g} \text {. } \\
\text { butter/ } \\
\text { day }\end{array}$ & $\begin{array}{l}\text { Intake } \\
\text { Urine } \\
\text { Faeces } \\
\text { Absorbed } \\
\text { \% Intake } \\
\text { absorbed }\end{array}$ & $\begin{array}{r}1,920 \\
679 \\
272 \\
1,648 \\
86 \\
\end{array}$ & $\begin{array}{r}16 \cdot 64 \\
7 \cdot 26 \\
6 \cdot 50 \\
10 \cdot 14 \\
61\end{array}$ & $\begin{array}{r}78 \cdot 2 \\
48 \cdot 6 \\
8 \cdot 2 \\
70 \cdot 0 \\
90\end{array}$ & $\begin{array}{r}79 \cdot 8 \\
45 \cdot 5 \\
9 \cdot 2 \\
70 \cdot 6 \\
89\end{array}$ & $\begin{array}{r}172 \cdot 3 \\
0 \cdot 7 \\
84 \cdot 5 \\
87 \cdot 8 \\
51\end{array}$ & $\begin{array}{r}52 \cdot 9 \\
12.8 \\
21.0 \\
31.9 \\
60\end{array}$ & $\begin{array}{r}74 \cdot 8 \\
40 \cdot 5 \\
2 \cdot 1 \\
72 \cdot 7 \\
97\end{array}$ & $\begin{array}{r}153 \cdot 60 \\
89 \cdot 40 \\
64 \cdot 20 \\
42\end{array}$ & $\begin{array}{r}8 \cdot 06 \\
3 \cdot 38 \\
1 \cdot 54 \\
6 \cdot 52 \\
81\end{array}$ & $20 \cdot 6$ \\
\hline
\end{tabular}

TABLE 3

EFFECT OF ADDING FAT TO DIET OF A PATIENT AGED $3 \%$ YEARS WITH CYSTIC FIBROSIS OF THE PANCREAS (From Chung et al., 1951)

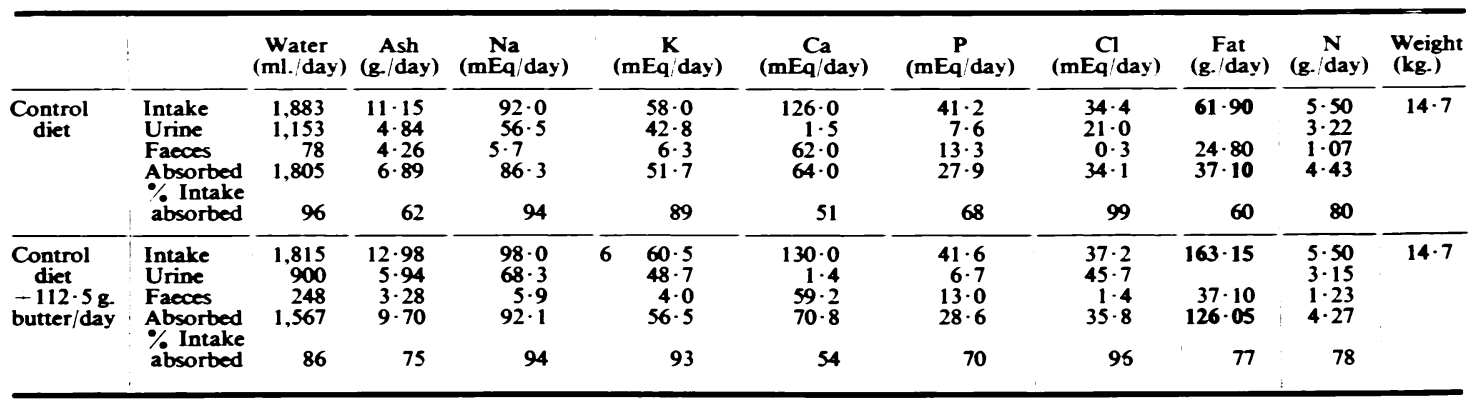

TABLE 4

EFFECT OF ADDING EXCESS FAT TO DIET OF 8-YEAR-OLD BOY WITH CONGENITAL ATRESIA OF BILE DUCTS (From Krahulik et al., 1952)

\begin{tabular}{|c|c|c|c|c|c|c|}
\hline \multirow[b]{2}{*}{ Diet } & & \multirow[b]{2}{*}{ Fat Intake (g. day) } & \multirow[b]{2}{*}{ Faecal } & \multirow[b]{2}{*}{ Fat (g/day) } & \multicolumn{2}{|c|}{ Fat Absorbed } \\
\hline & & & & & (g/day) & $\%$ of Intake \\
\hline $\begin{array}{l}\text { Evaporated milk } \\
\text { Evaporated milk }- \text { butter } \ldots \\
\text { Evaporated milk } \\
\text { Evaporated milk }- \text { butter } \ldots\end{array}$ & $\begin{array}{l}\cdots \\
\cdots \\
\cdots\end{array}$ & $\begin{array}{r}63 \cdot 2 \\
168 \cdot 8 \\
63 \cdot 2 \\
168 \cdot 8\end{array}$ & & $\begin{array}{l}36 \cdot 8 \\
90 \cdot 0 \\
37 \cdot 2 \\
82 \cdot 5\end{array}$ & $\begin{array}{l}26 \cdot 4 \\
78 \cdot 8 \\
26 \cdot 0 \\
86 \cdot 3\end{array}$ & $\begin{array}{l}41 \cdot 5 \\
46 \cdot 6 \\
41 \cdot 0 \\
51 \cdot 1\end{array}$ \\
\hline
\end{tabular}

Table 4 one with congenital biliary atresia. The linear relationship between fat intake and fat absorption in premature infants is shown in Fig. 2. A similar relationship between fat intake and fat absorption in patients with kwashiorkor has recently been demonstrated by Gomez and his colleagues in Mexico City (Gomez, Cravioto. Frenk and Ramos Galvan, personal communication).

Habits are hard to change and concepts with which we are thoroughly indoctrinated are hard to shake off. At least I have found it so, for I was thoroughly indoctrinated to rest a disordered intestine and impressed with the inevitable increase in stooling when this advice was not followed. In presenting the opposite viewpoint I must disclaim any originality for the philosophy back of it. Credit for that belongs to my teacher, Edwards A. Park, who wrote in 1923 (Park, 1924):

'The habit of starving an infant just because he has frequent stools is fallacious and gives rise to disastrous results.'

A similar statement was made in that same year by Schick and Wagner (Schick and Wagner, 1923) in Vienna. Speaking of the intestine in what we now call coeliac disease they wrote: 


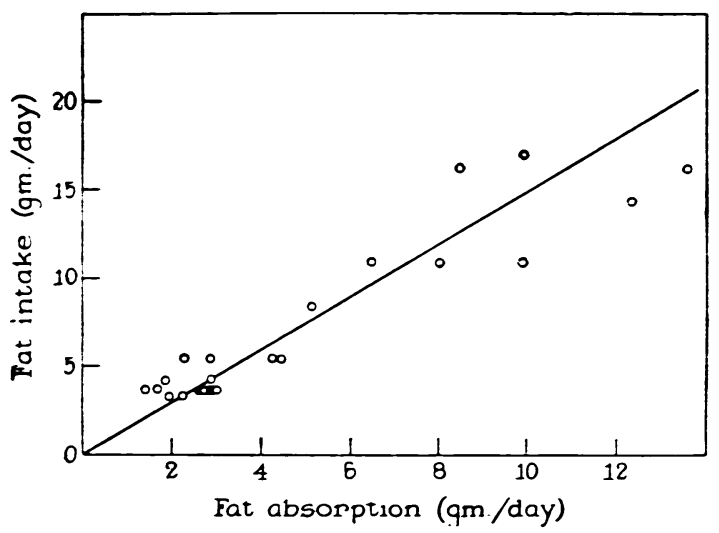

FrG. 2.-Relation of fat intake to fat absorption in premature infants. (From Morales et al., 1950.)

'these observations indicate that the therapy of sparing can do harm in such cases and that from the point of view of a return to health much more is to be expected from the therapy of use.'

These authors obtained chemical as well as clinical evidence to support the thesis that use rather than rest of a disordered intestinal function is beneficial. Table 5 shows one of their experiments illustrating

TABLE 5

EFFECT OF ADDING FAT TO DIET OF PATIENT WITH CHRONIC INTESTINAL INDIGESTION*

\begin{tabular}{ccc}
\hline Day & Diet & $\begin{array}{c}\text { Stool Fat } \\
\text { (g. day) }\end{array}$ \\
\hline $4 / 12 / 21$ & Control & $4 \cdot 4$ \\
$4 / 13 / 21$ & Control - 34 g. butter & $6 \cdot 6$ \\
$4 / 14 / 21$ & Control - 34 g. butter & $6 \cdot 7$ \\
$4 / 15 / 21$ & Control & $11 \cdot 7$ \\
$4 / 17 / 21$ & Control & $10 \cdot 4$ \\
4 & Control & $6 \cdot 0$
\end{tabular}

- Of $34 \mathrm{~g}$. fat added approximately $29 \mathrm{~g}$. were absorbed. (From Schick and Wagner, 1923.)

the effect of adding butter to the diet of a coeliac patient. Most of the added butter was absorbed; only a fraction went to increase the stool output. In giving credit to these pioneers I should be remiss if I did not mention the work of Macrae and Morris from Glasgow published in 1931. These workers had the courage to add large quantities of fat to the diet of several coeliacs and reported improved absorption despite increased stool losses. They were among the first to think in terms of nutrition rather than of digestion.

If a final blow were needed to give the coup de grâce to the doctrine of therapeutic starvation it is furnished by the recent observation of René Dubos (1955) who showed in experimental animals that a fast of 30 hours produced a demonstrable lowering of resistance to three types of bacterial infection which he studied, tuberculosis, staphylococcus and Friedländer bacillus infections.

I turn now to some observations we have made on the minimal requirements of certain nutrients, particularly the B vitamins and essential aminoacids. Someone may wonder why anyone bothers about minimum requirements which at first glance seem to have little practical value. Why not just give what seems to be clinically satisfactory in preventing deficiencies which should provide enough with a reasonable margin of safety? The answer to that query is that there are a number of circumstances in which it is important to know exact food requirements. It is important to have such information in conditions of food shortage. It is also needed in clinical situations where we are limited in our ability to give food, notably in disorders of the digestive tract. With a limited capacity to handle food we cannot afford to waste on unessentials what may be needed for essentials. We need to know

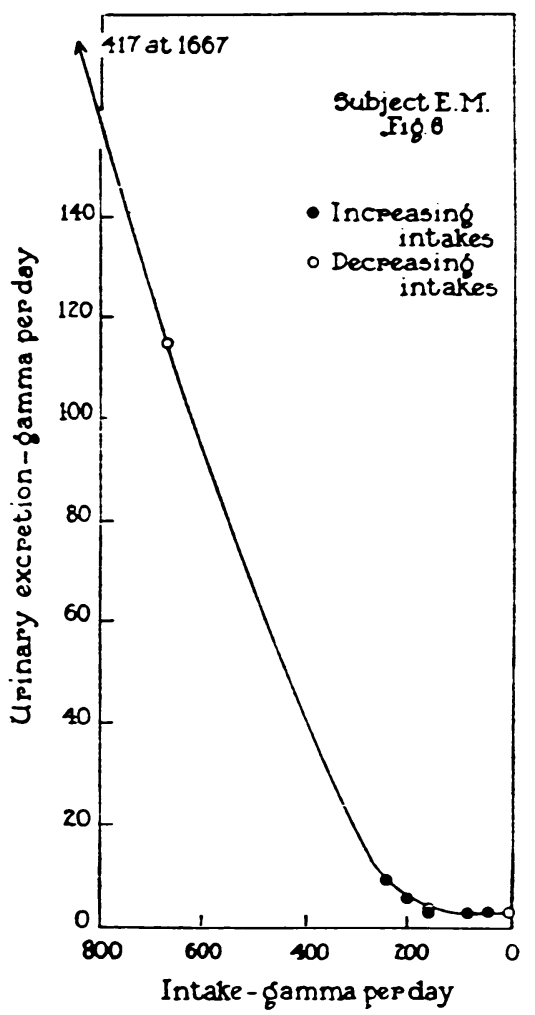

Fig. 3.-Relationship between thiamine intake and thiamine excretion in the urine of the infant. As the intake is decreased the urinary excretion falks to a minimum level of approximately 5 gamma per day. (From Holt et al., 1949.) 

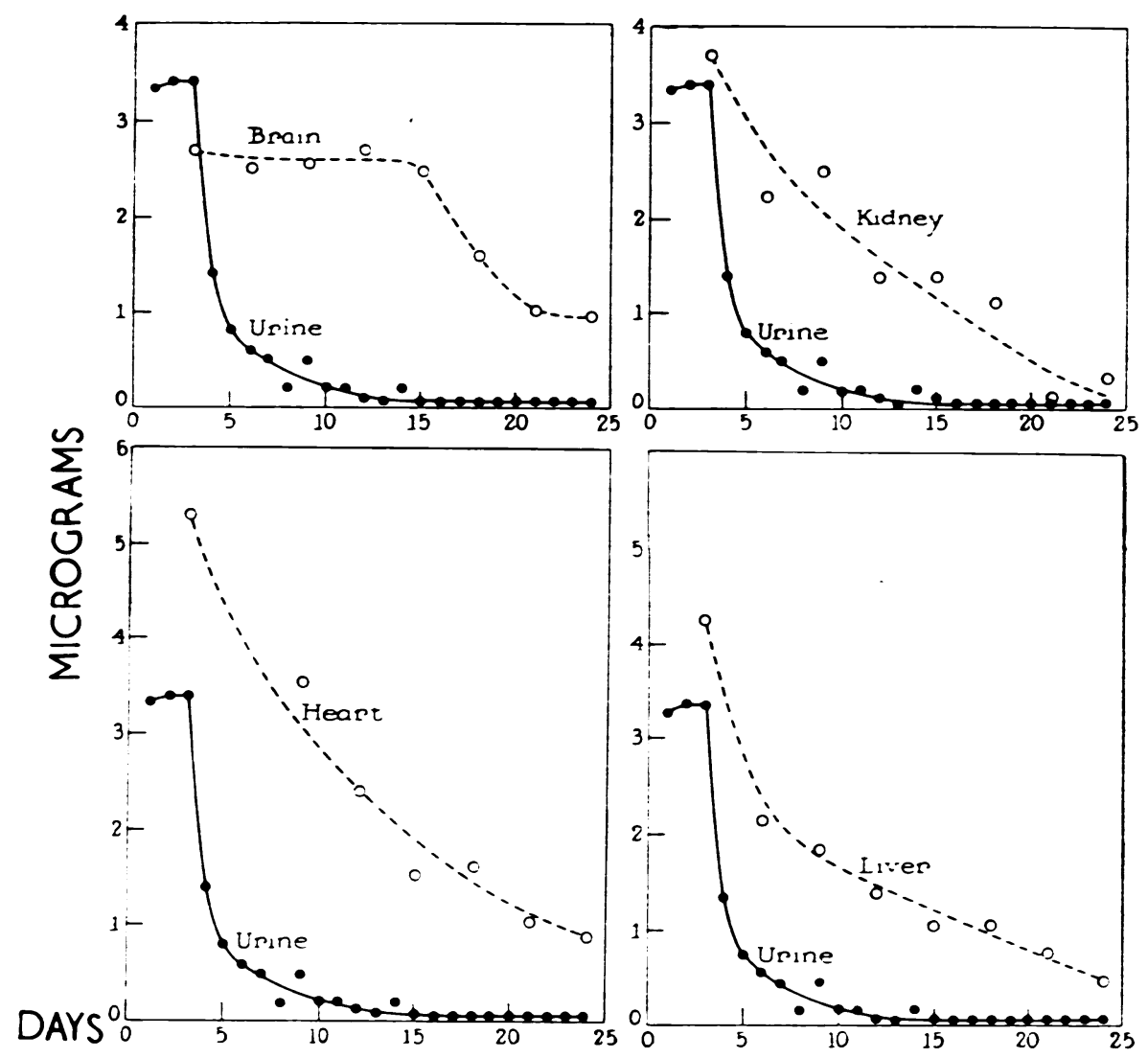

Frg. 4.- The relation between thiamine of tissues and thiamine excretion in urine of rats. Ordinates represent micrograms thiamine per g. dry tissue and micrograms per day of thiamine in urine. Abscissae represent days on thiamine-deficient diet. The tissue figures represent averages of four animals sacrificed. The urine figures represent averages of surviving animals. (From Salcedo et al., 1948.)

what is essential in order to avoid excesses that may be harmful as well as wasteful, and, finally, marginal studies are of great importance in defining criteria of adequacy in instances where these are in doubt; the development of reliable clinical and laboratory criteria may lead to the recognition of deficiency states where they are not known to exist.

Minimum requirement studies are difficult to carry out in infants. With adults one can get volunteers and deplete them until symptoms develop but with infants an ethical problem is involved. We have attempted to solve this difficulty by establishing in adults and in experimental animals biochemical data of incipient deficiency before clinical symptoms made their appearance. Such criteria of 'subclinical deficiency' were then applied to infants since there was no evidence of harm resulting therefrom.

In the case of several of the B vitamins the urinary excretion can be used as a criterion of adequacy.
As one reduces the intake of thiamine for example, and this was done on a synthetic diet consisting of vitamin-free casein, fat, carbohydrate, minerals and a mixture of pure vitamins, the thiamine excretion falls, eventually reaching a minimal point beyond which further decreases in intake cause no further drop in urinary excretion (Fig. 3). Evidence that this 'point of minimal excretion' coincides with the minimal requirement and that spill above this point represents surplus was derived from clinical observations on depleted adults (Holt, 1944) and from studies on depleted rats (Salcedo, Najjar, Holt and Hutzler, 1948). In these animals it was found (Fig. 4) that the nervous system retains its thiamine in the face of depletion until the 'point of minimal excretion' is reached, beyond which it begins to lose thiamine abruptly. By gradual adjustment of the thiamine intake we have determined the point of minimal excretion in seven infants and find that by 


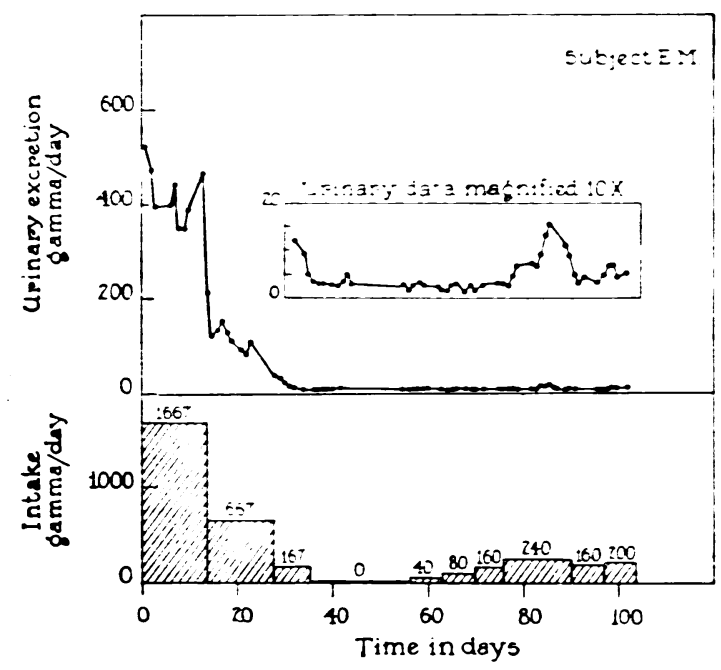

FKG. 5.-Determination of the point of minimal thiamine excretion in an infant. When the thiamine intake is increased above 160 gamma per day thiamine is excreted in the urine above the minimal level. (From Holt et al., 1949.)

this criterion the minimal requirement of thiamine varies from 0.16 to $0.20 \mathrm{mg}$. per day (Holt, Nemir, Snyderman, Albanese, Ketron, Guy and Carretero, 1949). We have studied the influence of various factors on the thiamine requirement: the effect of changing the proportion of caloric foodstuffs, the effect of changing the type of carbohydrate, of adding adsorbents and of giving antibiotics (Fig. 5). Increasing the carbohydrate calories caused some increase in thiamine requirement (Holt and Snyderman, 1955) (an increase from $0 \cdot 20$ to $0.28 \mathrm{mg}$. in the experiment shown in Fig. 6) but varying the nature of the carbohydrate, suppressing the intestinal flora or giving adsorbants had no demonstrable effect (Holt, 1950). Prolonged autoclaving destroyed thiamine in significant amounts.

FIG. 6.-Relation between composition of diet and thiamine requirement in an infant. Increasing the carbohydrate causes a drop in thiamine excretion to minimal levels. The original level of excretion is restored by raising the intake from 200 to 280 gamma per day. (From Holt and Snyderman, 1955.)
Turning to riboflavine (Fig. 7), we were able to evaluate the riboflavine requirement by a similar technique, a sharp break in the urinary excretion curve as the intake was reduced (Fig. 8). The minimum requirement obtained by the 'point of minimal excretion" technique was found to be a level which would barely maintain the riboflavine content of the red and the white blood cells. The minimal riboflavine requirement of the infant was found to be between 0.4 and $0.5 \mathrm{mg}$. per day (Snyderman, Ketron, Burch, Lowry, Bessey, Guy and Holt, 1949). Variations in the proportions of calorigenic foodstuffs (Fig. 9) in the type of carbohydrate, the addition of antibiotics and of adsorbants failed to influence the requirement. An interesting observation on the relation between riboflavine requirement and infection was made. One infant maintained on a constant riboflavine intake just above the minimal requirement level suffered a series of infections resulting each time in a temporary weight loss. Associated with each of these episodes was an outpouring of riboflavine in the urine. Our interpretation of this finding is that during these periods of stress the individual is living on his own tissues and that the riboflavine stored in them is then liberated, flooding the organism (Fig. 10). The administration of a riboflavine supplement at such a time would seem to be superfluous.

The nicotinic acid requirement of the infant was evaluated by means of the excretion of $\mathrm{N}$-methyl nicotinamide (N.M.N.) in the urine. It is well known that tryptophane can serve as a source of nicotinamide, but it was not known whether the tryptophane ordinarily supplied in milk formulas is
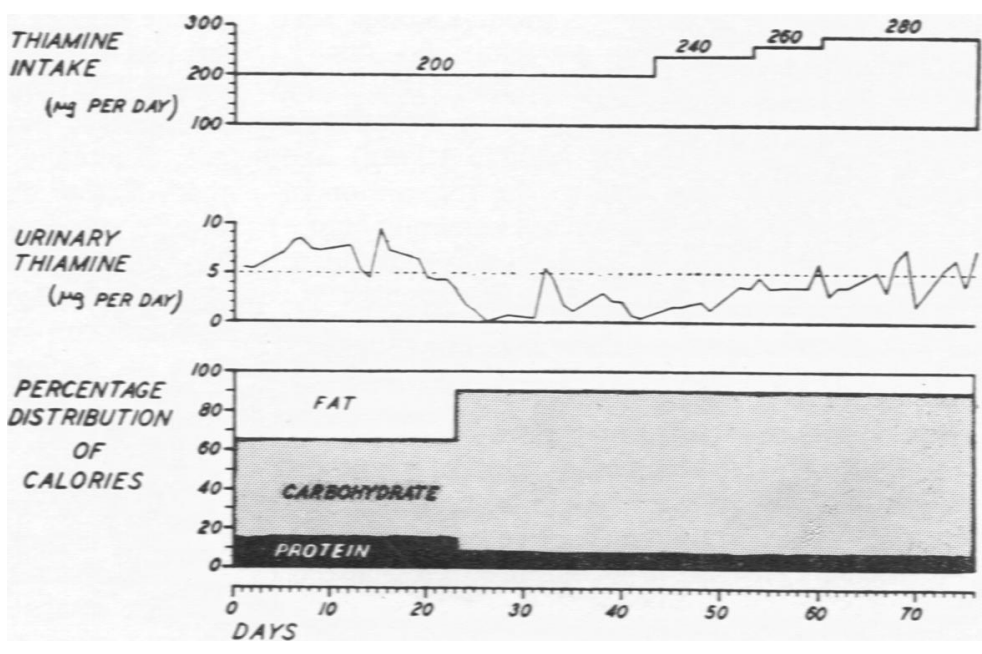


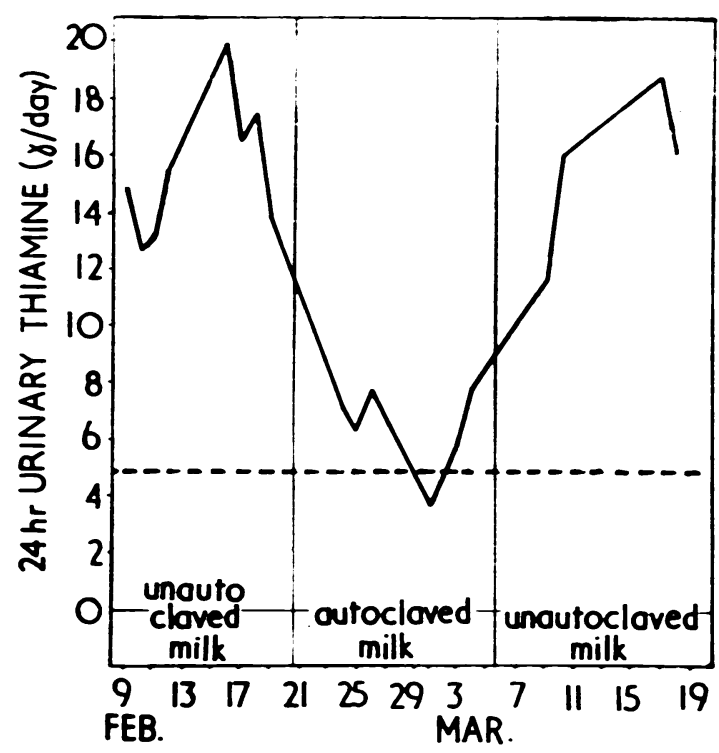

Fig. 7.-Prolonged autoclaving of milk for half an hour destroys enough thiamine to reduce the thiamine output in the urine to the minimal level. (From Snyderman and Holt, unpublished observations.)

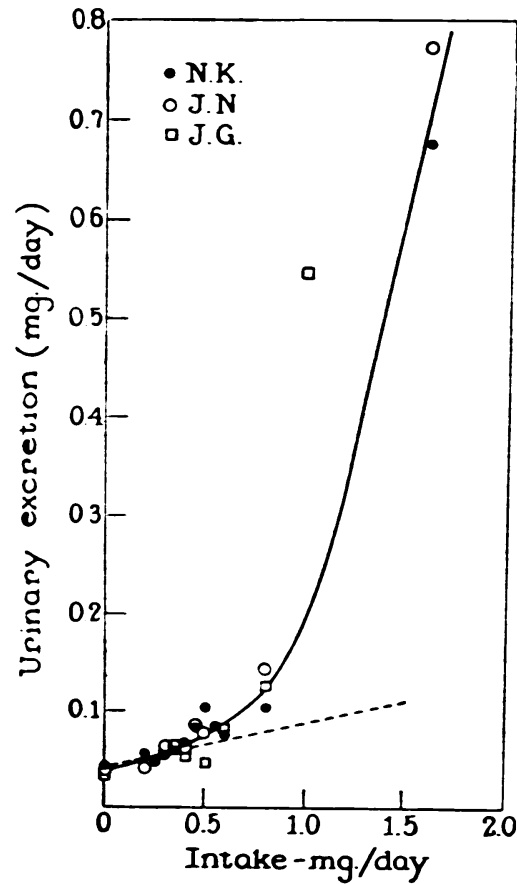

FK. 8.-Relation between riboflavine intake and riboflavine excretion in the urine. As the intake is decreased below $0.5 \mathrm{mg}$. per day the urinary riboflavine decreases only minimally. (From Snyderman et al., 1949.)

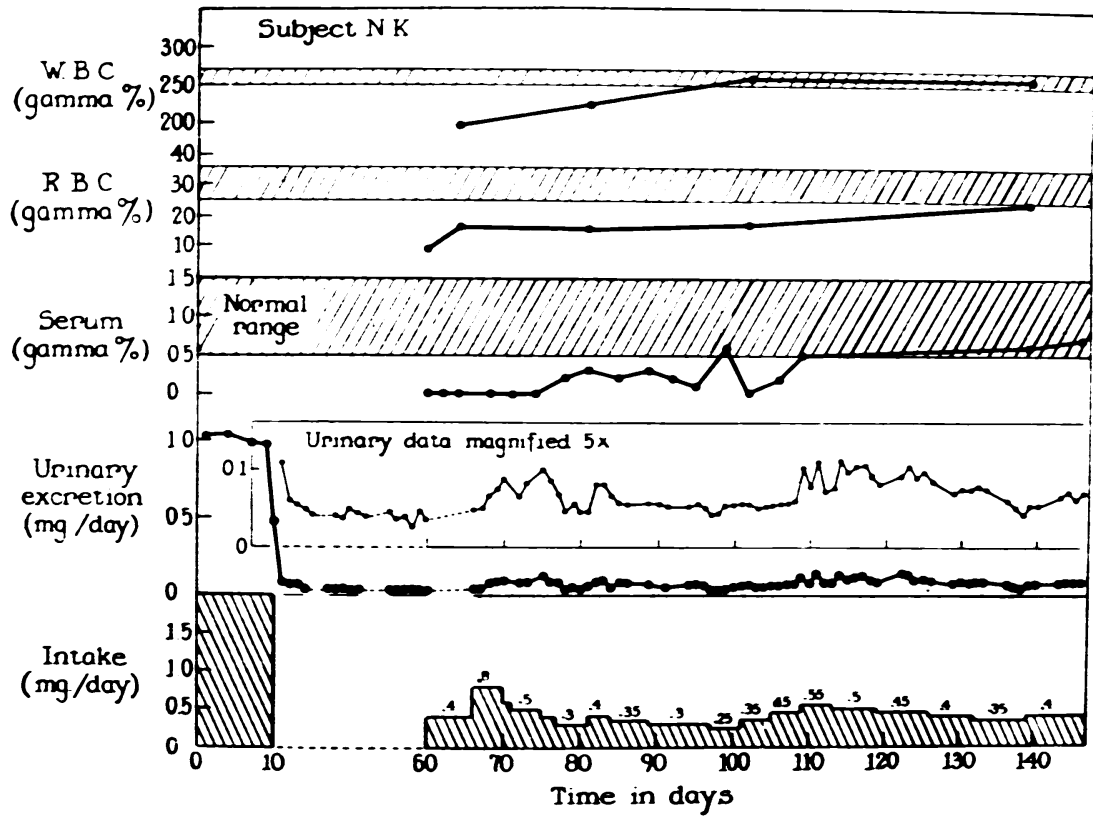

FKG. 9.-Determination of point of minimal excretion of riboflavine in an infant. Intakes above $0 \cdot 35 \mathrm{mg}$ cause increased spilling of riboflavine in the urine. Over a prolonged period intakes at or slightly above the minimal requirement level cause a gradual repletion of blood riboflavine values. (From Snyderman et al., 1949.) 


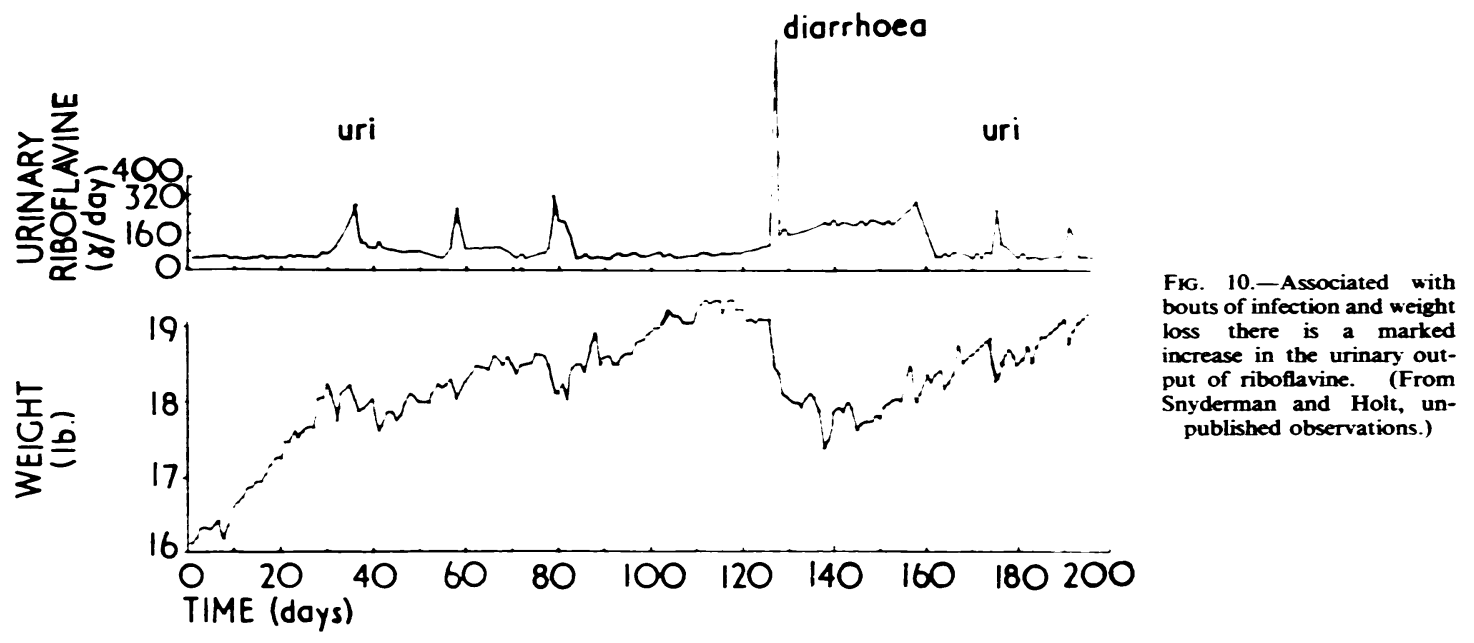

sufficient to cover the need for this vitamin. Fig. 11, illustrating an experiment on a synthetic diet containing no nicotinic acid whatever, shows that when $15 \%$ of the calories are supplied as casein the nicotinic acid requirements are more than met, for the N.M.N. remains above the minimum. When only $10 \%$ of the calories are supplied by casein the urinary excretion drops to the minimal value. Since there is some nicotinic acid in milk apart from that which can be derived from the dietary tryptophane, it would appear that we have an ample margin of safety in regard to this vitamin on the type of formula commonly used for infants.

Our studies established the essentiality of pyridoxine for the infant (Snyderman, Holt, Carretero, and Jacobs, 1953) and data on some of our American proprietary feedings where this vitamin was inadvertently destroyed to a variable extent have given us an accurate value for the requirements of infants (Holt, 1954). We have not been able to demonstrate the essentiality of folic acid under normal conditions. It would appear that biosynthesis of this factor takes care of needs reasonably satisfactorily, but when this is suppressed by antibiotics a folic acid deficiency develops readily (Fig. 12). In studies of several months' duration we have not been able to establish pantothenic acid or biotin as dietary essentials for the infant and the same is true for vitamin $B_{12}$. Most of the studies described to you were carried out before the discovery of $B_{12}$ which was therefore not provided in our synthetic vitamin mixture. Some 40 experiments, lasting many months, have been carried out on children receiving no known source of $B_{12}$, none of which point to an appreciable need for this factor. It is of course possible that minute amounts of $B_{12}$ were present in our vitamin-free casein which unfortunately is no longer available for assay. All we can say is that if there is a $B_{12}$ requirement it must be extremely small.

FIG. 11.- On a synthetic diet in which $15^{\circ}$, of the calories are derived from casein the excretion of N-methyl nicotinamide (N.M.N.) remains above the minimal value even when no nicotinic acid is fed. When the protein calories are reduced to $10^{\circ}{ }_{0}$, N.M.N. excretion fals to the minimal level. (From Snyderman and Holt, unpublished observations.)
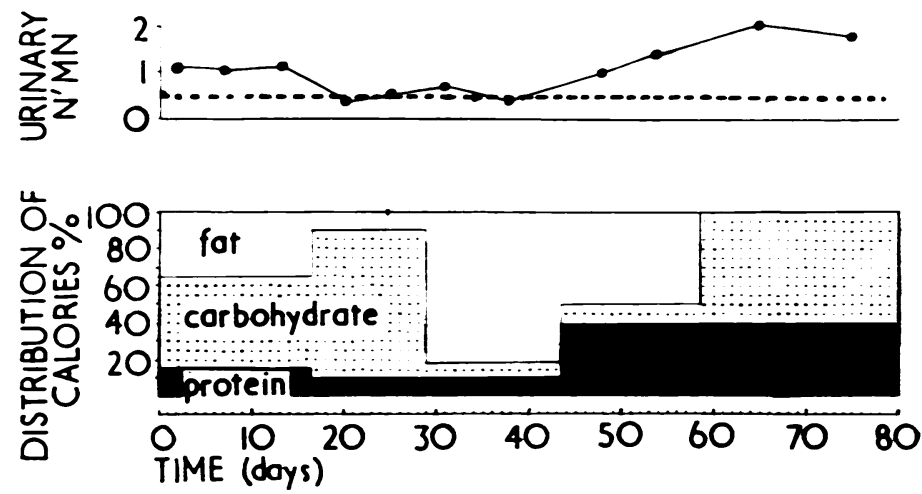


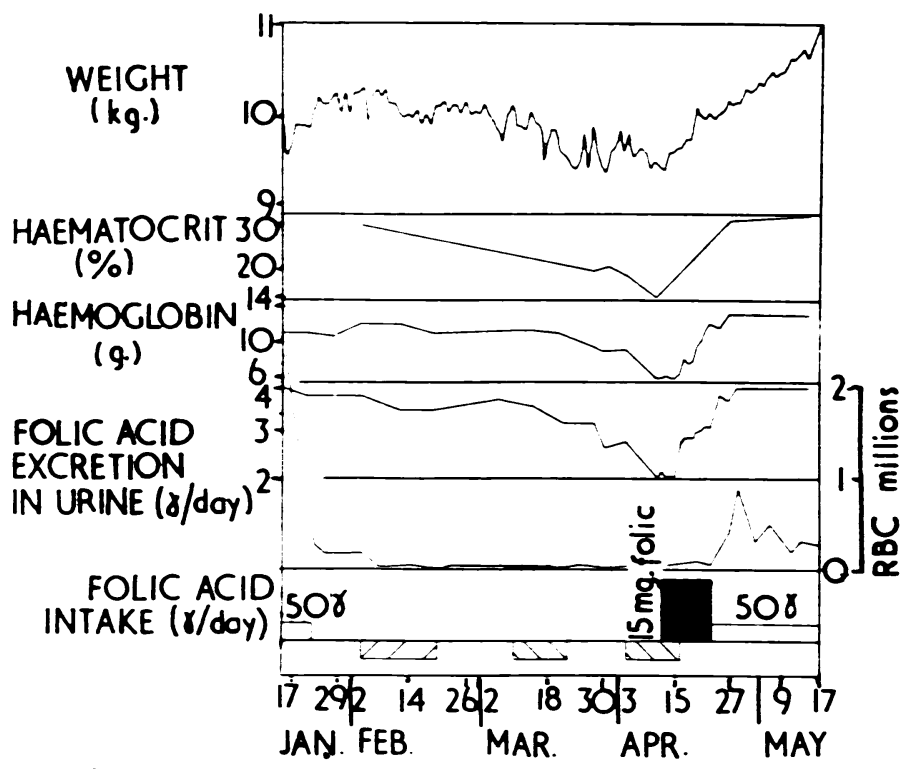

$5 \mathrm{mg}$. folic doily $=$ Strepromycin $\approx$ Sulfosuxidine

FIG. 12.-Elimination of folic acid from the diet together with the administration of antibiotics causes arrest of weight gain and the development of a macrocytic anaemia, both of which respond rapidly to the administration of folic acid. (From Snyderman and Holt, unpublished observations.)

We have some evidence for the existence of a dietary factor which still eludes us, which may be a B vitamin (Snyderman, Holt, Nemir, Guy, Carretero and Ketron, 1950). After five to seven months on our synthetic diet infants stop gaining weight though exhibiting otherwise every appearance of health (Fig. 13). Supplements of brewer's yeast will usually restore growth, but often only after a pause. The missing factor is definitely not $\mathbf{B}_{12}$.

We have made observations on essential aminoacid as well as on B vitamin requirements. This requires a basal diet deficient in the amino-acid to be studied which can be supplemented at any desired level. Early approaches to this problem were unsatisfactory. The use of deficient proteins is objectionable because in most of these there are multiple amino-acid imbalances. Chemical degradation of food proteins or hydrolysates is undesirable because of unknown degradation products. Mixtures of pure amino-acids can be used, but unless one uses only the natural L-forms one may encounter abnormal effects from the D-isomers, and unless the unessential amino-acids are provided these must be made from the essential ones which alters the requirements for the latter. We now use a synthetic diet in which nitrogen is supplied by a mixture of $18 \mathrm{~L}$-amino-acids in the proportions found in breast milk. With this diet any single amino-acid can be reduced at will (we have replaced it by an equivalent amount of glycine) until an intake is found which will no longer support normal growth and nitrogen retention. In this way we have been able to evaluate the requirement of the infant for threonine, phenylalanine and lysine as is shown in the accompanying figures. The data obtained indicate a requirement for threonine of $60 \mathrm{mg}$. per kg. per day, for phenylalanine of $90 \mathrm{mg}$. and for lysine of $90 \mathrm{mg}$. (Pratt, Snyderman, Cheung, Norton, Holt, Hansen and Panos, 1955; Holt and Snyderman, 1956; Snyderman, Pratt, Cheung, Norton, Holt, Hansen and Panos, 1955). Others are being studied and requirements obtained in our earlier studies with cruder techniques are being re-evaluated (Fig. 14).

Amino-acid requirements are assuming considerable importance in measures to control protein deficiency in many so-called underdeveloped countries. They are also giving us concern because of a new development in our country, namely, the commercial exploitation of essential amino-acids as food supplements. This promises to rival the vitamin exploitation which has reached deplorable proportions. In both instances exploitation has occurred because of lack of exact knowledge of requirements and of exact criteria of deficiency. In the case of the B vitamins the harm is largely in the economic waste; the margin of safety from the point

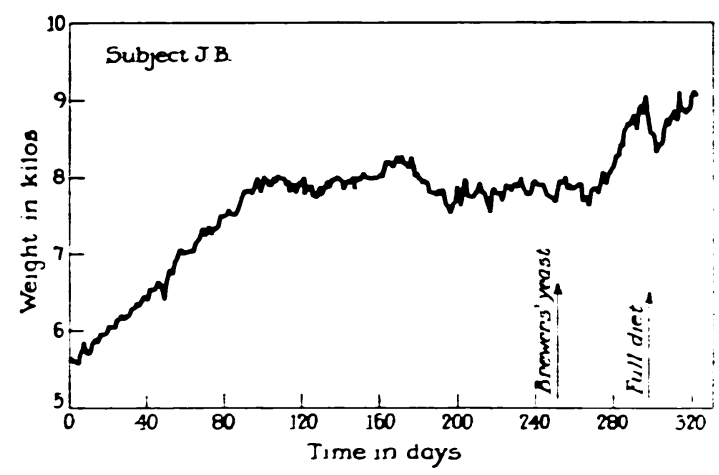

FIG. 13.- Infant fed on a synthetic diet composed of casein, fat, sugar, minerals and purified vitamins. Arrest of weight gain after 100 days without other evidence of impaired health. Supplementation with brewer's yeast was followed by a spurt in weight. (From Snyderman et al., 1950.) 


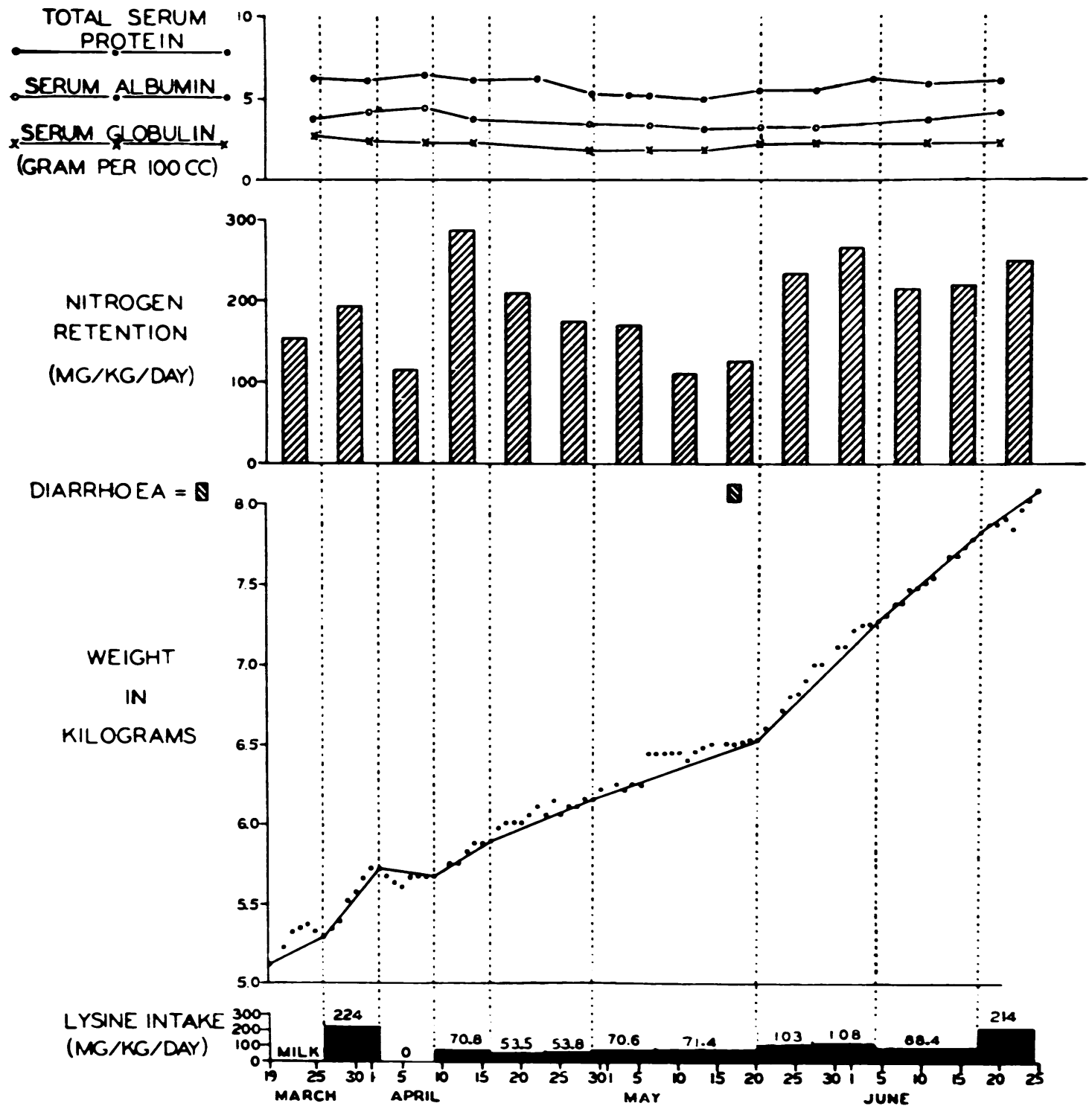

Fig. 14.-Lysine requirement of a normal infant aged $1 \frac{1}{2}$ months. An intake of $88.4 \mathrm{mg}$. per $\mathrm{kg}$. is sufficient to maintain a normal weight curve and to reduce a nitrogen retention of $200 \mathrm{mg}$. per day. (From Holt and Snyderman, 1956.)

of view of health is, in most instances, enormous. But in the case of lysine and some of the other amino-acids this is not the case; doubling the usual intakes may lead to amino-acid imbalance. Notable observations on the effect of lysine in humans have come from G. A. Rose at University College who has demonstrated important losses of three other amino-acids, cystine, arginine and ornithine in urine (Rose, 1956). Studies in animals (Elvehjem and
Harper, 1955) and on tissue cultures (Swim and Parker, personal communication) have shown how readily amino-acid imbalances can be produced.

The data that I have shown you all represent work done by others in our department. My own part has been a passive one. The list of active workers is a long one, but I must mention three of them very particularly: Dr. Arthur Chung, Dr. Edward Pratt and Dr. Selma Snyderman. 
In concluding I want to revert to the title of my paper and discuss where nutrition is going. There can be little doubt that we now know practically all the essential nutrients. When we can make a completely synthetic diet out of pure synthetic chemicals that will permit health and growth for an indefinite time we shall have reached that goal, but it looks as if we were almost there now, we can so nearly do it. The quantitative as well as the qualitative data will soon be at hand. But the future of nutrition as I see it, the big future which is just opening up, is the field of nutrition in disease rather than in health. In the last analysis cells which sicken and die from any pathological process do so because they are improperly nourished. They may die because of failure of some one of the 30 odd essential nutrients that we now recognize. They may die because of an abnormal requirement of one of our presently known nutrients. They may also die for lack of what I may call a conditional nutrient, a nutrient needed only in a particular pathological state, a stress nutrient if you will. I shall give a few examples of abnormal nutritive requirements in disease. To start with our familiar nutrients, we are all aware of increased caloric demands in fever and there is evidence, too, of an increased nitrogen requirement at this time. We are familiar with the demineralizing effects of acidosis and with an increasing number of situations causing potassium losses from the cells which need to be replaced. In resistant rickets we have an example of a condition requiring many times the usual requirement of vitamin $D$; in the premature there is an exceptional need for C. A condition demanding an excess of $B_{6}$, pyridoxine dependency, has been described. Most of us pay little attention to a need for essential fatty acids. We know that the rat will develop a scaly tail if he does not have them, and the dog, too, suffers on a completely fat-free diet (Wiese, Baughan and Hansen, 1955), but such long-term studies as have been done on infants indicate no more than a suggestion of increased skin difficulties. Recent observations of Peifer and Holman (1955) and by Kinsell, Michaels, Partridge, Boling, Balch and Cochrane (1953) have, however, shown us that certain stresses can greatly increase the requirement for essential fatty acids. A deficit of $\mathbf{B}_{i}$ will do this, for this vitamin catalyses the synthesis of the needed arachidonic from the more abundant linoleic acid in ordinary diets. Feeding cholesterol and, even more so, any condition associated with hypercholesterolaemia markedly increases the need for essential fatty acids. Clinical observations from South Africa (Bronte-Stewart, Antonis, Eales and Brock, 1956) indicate that fish oils rich in higher unsaturated fatty acids will lower blood cholesterol levels in patients with idiopathic hypercholesterolaemia.

Perhaps $B_{12}$ is an essential nutrient for the human. The evidence on this point is not yet clear. It is clear that it is not essential for certain ruminants which can synthesize it in the gut if they are given enough cobalt. The report of Sinclair and his associates (Wokes, Badenoch and Sinclair, 1955) that complete vegetarians or vegans fail to thrive after a time if they receive no animal protein is suggestive but not conclusive. But even if we do need $B_{12}$ we need it only in traces in contrast to the far greater quantity needed by the patient with pernicious anaemia. The observations of Bodian (Bodian, 1955) on the effect of large doses of $B_{12}$ on neuroblastoma have perhaps not provided the cure for that disease, but I want particularly to comment on them because I think they illustrate a principle the significance of which is not generally appreciated, the principle that different cells have different nutritive requirements. A dietary factor may upset the balance between malignant and non-malignant cells and I believe that nutrition is today one of our most hopeful approaches to the problem of neoplastic disease. I should like to mention another illustration of this approach which comes from the laboratory of J. B. Allison at Rutgers University (Allison, 1956). In studying malignant tumours in dogs and their destruction by the phosphoramide compound TEPA Allison found that with the more malignant tumours the host could not tolerate the dose of the agent required to kill the tumour. However, by using extremely large doses of two methylating agents, methionine and glycocyamine, he was able to build up the resistance of the host and enable the host to tolerate the effective tumour-destroying dose of the agent. Is it a coincidence that $B_{12}$ is also concerned in methylations?

Degenerative diseases and anomalies of metabolism are hopeful fields for the discovery of a missing nutrient that can be supplied. Tyrosine is ordinarily an unessential in diet for the body can make it from phenylalanine. In the phenylketonuric child, however, it is essential. Tyrosine formation from phenylalanine is then virtually nil and unless an adequate amount of tyrosine is given as such melanin formation suffers.

The nutrition of the future will deal with many substances which we do not regard as nutrients today. They are cell nutrients, substances which under normal conditions may be elaborated within the body. We know little about them now. We shall learn much more from tissue culture studies 
with synthetic media. Many of our hormones, perhaps all of them, belong to this category, but they are only a few of the substances which are concerned with cellular metabolism. To introduce complex substances within the cell may be difficult and perhaps impossible, but it may not be necessary to do this. A simple prosthetic group may be all that is needed, a 'stress vitamin'. Perhaps the premature infant dies because he has not learned how to make certain enzymes that his more mature brother can make without difficulty. Perhaps he needs a spxcial set of vitamins to supply the prosthetic groups for these enzymes.

We have nearly completed our knowledge of nutrition in health but we have scarcely begun to scratch the surface of the vast field of nutrition in disease. I do not expect to see much of that development myself. I expect to be kept busy for my few remaining years trying to finish up some of the more elementary things I have been telling you about. This future development, the maturity of nutrition we can only see dimly at present, but that it will serve paediatrics even better than the nutrition of the past is something I have no doubts about. The nutritionist of the future, and the man who applies nutrition to paediatrics, will be a different kind of person from the one of the past. He will be less concerned with rat growth and the external appearance of a rat's tail, but he will know far more about enzymes and about the intermediary metabolism of cells in vivo and in vitro. Let us encourage our young investigators to follow this path and to keep it in good repair.

Allison. J. B. (1956). In 4 Symposium on Amino Acid Supplementation. Twelfth Annual Conference on Protein Metabolism. Rutgers University Press. New Brunswick. N.J.
Bodian, M. (1955). Med. Press, 234, 350.

Bronte-Stewart. B., Antonis, A., Eales, L. and Brock, J. F. (1956). Lancet, 1. 521.

Chung. A. W. (1948). J. Pediat., 33, 1.

- and Holt, L. E. Jr. (1950). Pediatrics, 5, 421.

and Vičorová, B. (1948). J. Pediat., 33, 14

Morales, S., Snyderman, S. E., Lewis, J. M. and Holt. J. E. Jr. (1951). Pediatrics, 7. 491.

Dubos, R. J. (1955). Bull. N.Y.Acad. Med., 31. 5.

Elvehjem, C. A. and Harper, A. E. (1955). J. Amer. med. Ass., 158. 655.

Gomez, F., Cravioto, J.. Frenk, S. and Ramos Galvan, R. Personal communication from Dr. Silvestre Frenk.

Holt. L. E. Jr. (1944). Neb. St. med. J., 29, 304.

(1950). Studies on B Vitamin Requirements of Infants. Nutrition Symposium Series No. 2. National Vitamin Foundation, New York.

- (1954). In Vitamin B6 in Human Nutrition. Proc. Tenth M \& R Pediatric Research Conference. 1953, p. 35. M \& R Laboratories, Columbus, Ohio.

- and Snyderman. S. E. (1955). J. Nutr., 56. 495.

- (1956). The Amino Acid Requirements of Infants. Twelfth Annual Conference on Protein Metabolism. Rutgers University Press. New Brunswick, N.J.

University Press, New Brunswick, N. . Nemir, R. L., Snyderman, S. E., Albanese, A. A., Ketron,
K. C.. Guy, L. P. and Carretero. R. (1949). J. Nutr., 37. 53.

Kinsell. L. W.. Michaels, G. D., Partridge, J. W., Boling. L. A., Bakch. H. E. and Cochrane, G. C. (1953). J. clin. Nutr., 1, 224.

Krahulik. L.. Shoob. M. P., Morales, S., Snyderman, S. E. and Holt, L. E. Jr. (1952). J. Pediat., 41, 774.

Macrae. O., and Morris, N. (1931). Archives of Disease in Childhood, 6, 75 .

Morales, S. Chung, A. W., Lewis, J. M., Messina. A. and Holt, L. E. Jr. (1950). Pediatrics, 6, 86.

Park, E. A. (1924). N.Y. St. J. Med., 24, 921.

Peifer, J. J. and Holman, R. T. (1955). Arch. Biochem. Biophys., 57. 520 .

Pratt, E. L. Snyderman, S. E., Cheung, M. W.. Norton, P., Holt, L. E. Jr., Hansen. A. A. and Panos, T. C. (1955). J. Nutr., 56. 231 .

Rose. G. A. (1956). Thesis, Oxford University.

Sacedo, J. Jr., Najjar, V. A., Holt, L. E. and Hutzler, E. W. (1948). J. Nutr., 36, 307.

Schick, B. and Wagner, R. (1923). Z. Kinderheilk. 35, 263.

Snyderman S. E. Holt, L. E. Jr., Carretero, R. and Jacobs, K. G. (1953). J. clin. Nutr.. 1. 200. K. Nemir, R. L., Guy, L. P., Carretero, R. and Ketron, K. C. (1950). J. Nutr., 42. 31

- Ketron, K. C.. Burch, H. B., Lowry, O. H., Bessey, O. A. Guy, L. P. and Holt, L. E. Jr. (1949). Ibid., 39, 219. Pratt. E. L.. Cheung. M. W.. Norton. P.. Holt. L. E. Jr. Hansen, A. E. and Panes, T. C. (1955). Ibid., 56. 253.

Swim, H. E. and Parker, R. F. Personal communication.

Swim, H. E. and Parker, R. F. Personal communication. 14. 453 .

Wokes. F.. Badenoch. J. and Sinclair. H. M. (1955). Amer. J. clin. viutr., 3, 375 